\title{
Bacterial community patterns of domestic water sources in the Gogogo and Nkonkobe areas of the Eastern Cape Province, South Africa
}

\author{
M Zamxaka, G Pironcheva and NYO Muyima* \\ Environmental and Natural Products Biotechnology Research Group, Programme Unit of Biochemistry and Microbiology, \\ University of Fort Hare, P/B X1314, Alice 5700, South Africa
}

\begin{abstract}
In the present study we have characterised the microbiological quality of the drinking water from different water sources in Gogogo and Nkonkobe areas in the Eastern Cape Province, South Africa. Using both standard microbiological methods and the commercial API 20E assay kit, we have been able to identify 54 different species of micro-organisms, $77.5 \%$ of which proved to be human pathogens, $53.2 \%$ of them, belonging to the family Enterobacteriacae and $22.5 \%$ were non-pathogens. Further investigations revealed a marked difference both in terms of the number and in the variety of organisms during different seasons. Thus the highest number of bacteria, i.e. $45.74 \%$ for Gogogo drinking water sources and $48.1 \%$ for Nkonkobe was registered in winter, while the lowest, i.e. $14.18 \%$, for Gogogo and $10.94 \%$ for Nkonkobe water sources was recorded in spring. Considering the overall bacterial community pattern of domestic water sources in the Gogogo and Nkonkobe areas, it can be concluded that the water is of poor microbial quality and requires extensive purification before any domestic use can be considered.
\end{abstract}

Keywords: bacterial community pattern, total coliforms, pathogenic bacteria, API 20E assay, Shannon-Weaver index $(\mathrm{H})$

\section{Introduction}

Water-borne diseases are one of the major causes of increased morbidity and mortality in the world, water being known as a carrier of human disease-causing organisms that can pose health risks to people if it is not properly treated. Diseases, such as cholera, salmonellosis, typhoid fever, to name a few, are most often associated with inferior water quality (Briggs et al., 1996).

Many people in rural areas, such as in Gogogo and Nkonkobe in the Eastern Cape Province of South Africa, use water of inferior quality for daily sustenance. The reason is that these people do not have continuous and ready access to treated water supplies and are therefore compelled to use untreated water or water supply of inferior quality for drinking and other domestic uses, such as food preparation and bathing (Von Schirnding, 1992).

Our previous studies (Muyima and Ngcakani, 1998; Zamxaka et al., 2004) have shown that the water from the Gogogo and Nkonkobe water sources is of poor quality and is not safe for human consumption, since its levels of contamination are high and exceed the South African recommended and allowable limits for microbiological indicators (DWAF, 1998). Almost all indicator bacteria counts, namely - heterotrophic, total and faecal coliforms were above the limits imposed in terms of the South African Standards (Zamxaka et al., 2004).

Analysts generally do not directly test for microbial pathogen species in water, since this is a complex and expensive exercise, especially in developing areas. Data on the health related quality of water are generally obtained from affordable alternative methods,

* To whom all correspondence should be addressed. 盄+2740 602-2364; fax:+27 40 602- 2429; e-mail: omuyima@ufh.ac.za Received 20 Augusty 2003; accepted in revised form 15 March 2004. such as the use of classical microbiological indicators of water quality, e.g. Escherichia coli. Results from these methods at best offer only a screen of microbial contamination and can at best only indicate the potential of water to infect consumers. Several incidents have been reported, where the absence of indicator organisms, such as E. coli, from a test sample does not actually indicate the absence of infection potential.

Both living organisms and bacterial breakdown products (metabolites, such as bacterial endotoxins released after the death of bacteria) can cause adverse inflammatory reactions such as fever and diarrhoea. Most of the screening assays for microbial contamination rely on the presence of the culturable organisms in the water (Mimms, 1990). It is well known that some of the most toxic bacterial breakdown products can withstand most of the treatments that are used to kill living organisms, i.e. chlorination and boiling. While a microbiological screening test might indicate that there are no culturable organisms in a water volume, microbial breakdown products might still be present in sufficient concentrations to cause adverse human health when ingested. Environmental engineers treating water for human consumption need to be sure that water produced in a treatment facility will not cause diseases such as diarrhoea, therefore being fit for human consumption, not merely being free of culturable indicator bacteria.

Methods for testing water for its inflammatory reactivity potential (direct human biomarkers for causing fever and diarrhoea) could supplement classical screening methods for identifying a vast number of both pathogenic and non-pathogenic micro-organisms. One of the best commercial testing kits on the market, ideal for the examination of enteric bacteria (Clayton, 1999), used in our studies, is the API 20E. It contains freeze-dried biochemical substances in small plastic cups, and the test is easy to interpret. This ensures that provisional diagnosis of Salmonella and Shigella, 
for instance could be made quickly and with greater confidence.

The aim of the present study was to analyze the bacterial community in domestic water sources of the Gogogo and Nkonkobe areas and to investigate the influence of different seasons on the species diversity. The study also determined the proportion between pathogenic and non-pathogenic bacteria in the Gogogo and Nkonkobe domestic water sources.

\section{Materials and methods}

\section{Water sampling}

The study sites comprised a main storage tank, a pipe, dams, wells, springs, streams, and various sites on the Thyume River, all located in the rural areas of Gogogo and Nkonkobe. Water samples were collected in $1 \ell$ flasks and transported on ice to the laboratory.

\section{Microbiological analysis}

Water samples were directly collected from the sources used by the communities to draw water for domestic use. These included the Thyume River, dams, wells, and springs. Samples were analyzed for total coliforms, Escherichia coli, Salmonella, Shigella and Vibrio using classical presumptive methods. The suspected colonies were then further purified and identified using the API $20 \mathrm{E}$ commercial identification kit.

The following culture media were used: xylose desoxycholate (XLD) agar, McConkey agar, nutrient agar (NA), tryptone soya agar (TSA) oxoid, triple sugar iron (TSI) agar oxoid, Vibrio diagnostic agar (VDA), m-Endo-Les agar, Gram-negative (GN) broth, thiosulfate-citrate-bile salts (TCBS), and tetrathionate broth (Biolab Diagnostics LTD, Midrand, South Africa).

\section{Isolation and identification of presumptive species}

\section{Total coliforms}

After using the membrane filtration method, the membranes were placed on m-Endo-Les agar plates and incubated at $37^{\circ} \mathrm{C}$ for $24 \mathrm{~h}$ (Grabow et al., 1991). Metallic sheen colonies appearing on the filter were randomly picked and purified using multiple subculturing. Thereafter a single colony of a randomly selected isolate was suspended in $5 \mathrm{~m} \ell$ of sterile distilled water and the suspension used in the API 20E assay.

\section{Salmonella species}

A sample aliquot of $500 \mathrm{~m} \ell$ was centrifuged at $10^{4} \mathrm{x} g$ for $10 \mathrm{~min}$ in order to concentrate the organisms. The supernatant was discarded until about $20 \mathrm{~m} \ell$ remained at the bottom of the centrifuge tube. This remaining suspension was then used for the isolation of Salmonella species. The suspension was enriched in tetrathionate broth in a 1:1 ratio relative to sample volume and incubated for 18 to $24 \mathrm{~h}$ at $25^{\circ} \mathrm{C}$. Using an inoculating wire, a loop full of the enriched culture was streaked onto the XLD agar plate and incubated at $35^{\circ} \mathrm{C}$ for 18 to $24 \mathrm{~h}$. Red colonies with black spots were transferred to NA and incubated at $35^{\circ} \mathrm{C}$ overnight. After multiple sub-culturing, isolates were pre-identified using Gram staining, oxidase, rapid indole, urease, Voges-Proskauer (VP), and orthonitrophenyl-2-D-galactopyranoside (ONPG) tests. Single colonies were isolated on NA and were used in the API 20E assay.

\section{Shigella species}

The same centrifugation procedure as described for Salmonella species was used to concentrate the organisms and $20 \mathrm{~m} \ell$ of the remaining bottom suspension used for the isolation of Shigella species. The enrichment and culturing conditions were similar to the ones used for salmonellas. Using an inoculating wire, a loop full of the enriched culture was streaked onto the XLD agar plate and incubated at $35^{\circ} \mathrm{C}$ for 18 to $24 \mathrm{~h}$. Colourless colonies with black spots were isolated, transferred to NA and incubated at $35^{\circ} \mathrm{C}$ overnight. After purification, single colonies were pre-identified using the same classical biochemical tests as described above. Then randomly selected isolates were further identified using the API 20 E assay.

\section{Vibrio species}

Water samples for the isolation of Vibrio were also concentrated by centrifugation as described previously while the enrichment was performed in alkaline peptone broth $(20 \mathrm{~g}$ peptone, $10 \mathrm{~g} \mathrm{NaCl}$, in $1 \ell$ of distilled water, $\mathrm{pH} 8.4$ ), using a 1:1 ratio of broth relative to sample volume. Double peptone broth in this case was used as an enrichment medium. The enriched cultures were incubated for 18 to $24 \mathrm{~h}$ at $25^{\circ} \mathrm{C}$ upon which a loop full of the enriched broth was streaked onto the thiosulfate-citrate-bile salts (TCBS) agar plate and incubated at $35^{\circ} \mathrm{C}$ for 18 to $24 \mathrm{~h}$. Suspected Vibrio cholera colonies appearing yellow on TCBS were transferred to nonselective medium, tryptone soya agar, or black agar containing a minimum of $0.5 \% \mathrm{NaCl}$. The plates were incubated at $35^{\circ} \mathrm{C}$ for $24 \mathrm{~h}$. The pre-identification was carried out as previously described and randomly selected isolates grown on tryptone soya agar used in the API 20E assay.

\section{Identification of bacteria using the API 20E assay}

Isolates used here were randomly selected using a random table to bring them to an economically acceptable number (i.e. from 1,510 to 338 isolates) for API identification. The API20E kit (bioMérieux, Lyon, France) was used according to the manufacturer's instructions. This is an identification system for Enterobacteriacae and other non-fastidious Gram-negative rods. The system uses 21 standardised and miniaturised biochemical tests strips and the APILAB Plus software Version 3.3.3 identification databases to interpret the tests.

\section{Results}

Our previous results (Zamxaka et al., 2003) on the microbiological quality of the domestic water sources, used by Gogogo and Nkonkobe rural communities showed that the water was of poor quality. Previous experiments indicated also that both the total and faecal coliform counts were above South African recommended standards. These results indicated the presence of total coliform and faecal coliform in the order of 4 logs per $100 \mathrm{~m} \ell$ of dam water. In the present investigation the aim was to identify and to compare the bacterial species in the water samples obtained from Gogogo and Nkonkobe domestic water sources. Secondly, we studied the temperature dependence, in terms of seasonal variation, of these micro-organisms and their overall distribution within a year.

In total 338 isolates from both Gogogo and Nkonkobe water supplies were analysed - 155 isolates from Gogogo water sources and 183 from the Nkonkobe area. Standard microbiological methods were used for the identification of total coliforms, Salmonella spp., Shigella spp., Vibrio spp., as well as a commercial testing kit - API 20E, which uses 21 standardised biochemical tests. All these methods allowed us to identify 54 different species of micro-organisms, including both pathogenic and non-pathogenic ones (Table 1). The occurrence of these 54 species in terms 
of seasons for Nkonkobe and Gogogo respectively is also given (Tables 2 and $3)$.

\section{Discussion}

The purpose of the work presented here was to analyze the bacterial communities in the domestic water sources of two different rural areas in the Eastern Cape. Secondly, it was of interest to determine the distribution of the different species during the different seasons, that is, in terms of temperature. A comparison of the distribution of micro-organisms in the two regions gave us an insight about the level of contamination of domestic water sources. Our previous studies showed that heterotrophic bacteria counts, total coliforms and faecal coliforms' counts were above the limits imposed in terms of the South African standards (Zamxaka et al., 2004). The present study confirmed the previous results and further showed the presence of 54 different bacteria species, of which $77.5 \%$ were known as human pathogens. $53.2 \%$ of them belonged to the family Enterobacteriacae, responsible for enteric diseases, which might be fatal. Several enteric genera contain important human pathogens, responsible for a variety of diseases: Escherichia coli - enteritis, Salmonella - typhoid fever and gastroenteritis, Klebsiella - pneumonia, Yersinia - plague, Serratia - abscesses, osteomyelitis, Hafnia alvei - liver and brain damage, Enterobacter-enteritis, Citrobacter - enteritis, haemolytic uraemic syndrome, Morganella morganii - urinary tract infections, Proteus - urinary tract infections (Prescott et al., 1999). Only 22.5\% of the micro-organisms, identified, proved to be non-pathogenic to humans. The high number of species isolated from the domestic water sources in the two areas, as well as the high Shannon-Weaver diversity index $(\mathrm{H})$ was an indication of high bacterial contamination of the water. The bacterial community in both water sources was dominated by Enterobacter and Serratia species.

Results on the distribution of bacteria in the domestic water sources during different seasons showed that the highest contamination occurred in winter $45.74 \%$ of micro-organisms for Gogogo domestic water sources and $48.1 \%$ for Nkonkobe. One plausible explanation is the predominant number of Enterobacter spp. and Serratia spp., which can survive at temperatures of $4^{\circ} \mathrm{C}-5^{\circ} \mathrm{C}$. Enterobacter cloacae for instance, seemed to be the
TABLE 1

Summarised bacterial community pattern expressed as percentage of occurrence with calculated Shannon-Weaver Index $(H)$ and evenness $(e)$ of domestic water source samples from the Gogogo and Nkonkobe rural areas in the Eastern Cape Province of South Africa, July 2001 to July 2002.

\begin{tabular}{|c|c|c|c|c|}
\hline \multirow[t]{2}{*}{ Bacterial species } & \multicolumn{2}{|c|}{ Gogogo } & \multicolumn{2}{|c|}{ Nkonkobe } \\
\hline & $\begin{array}{l}\text { Number } \\
\text { of isolates }\end{array}$ & $\%$ & $\begin{array}{c}\text { Number } \\
\text { of isolates }\end{array}$ & $\%$ \\
\hline 1 Acinetobacter baumanni & 0 & 0 & 3 & 1.64 \\
\hline 2 Aeromonas salm. salmonicida & 1 & 0.64 & 4 & 2.18 \\
\hline 3 Aeromonas hydrophila gr. & 9 & 5.81 & 11 & 6.01 \\
\hline 4 Burkholderia cepacia & 1 & 0.64 & 0 & 0 \\
\hline 5 Cedecea davisae & 0 & 0 & 1 & 0.25 \\
\hline 6 Chromo. violaceum & 0 & 0 & 3 & 1.64 \\
\hline 7 Chryseomonas luteola & 9 & 5.81 & 12 & 6.56 \\
\hline 8 Citrobacter koseri & 0 & 0 & 1 & 0.55 \\
\hline 9 Citrobacter braakii & 3 & 1.94 & 1 & 0.55 \\
\hline 10 Citrobacter freundii & 2 & 1.29 & 6 & 0.28 \\
\hline 11 Citrobacter youngae & 0 & 0 & 1 & 0.55 \\
\hline 12 Escherichia coli & 3 & 1.94 & 4 & 2.18 \\
\hline 13 Enterobacter asburiae & 1 & 0.64 & 0 & 0 \\
\hline 14 Enterobacter aerogenes & 0 & 0 & 1 & 0.55 \\
\hline 15 Enterobacter amnigenus & 2 & 1.29 & 0 & 0 \\
\hline 16 Enterobacter cloacae & 17 & 10.97 & 13 & 7.1 \\
\hline 17 Enterobacter fergusoni & 0 & 0 & 1 & 0.55 \\
\hline 18 Enterobacter gergoviae & 1 & 0.64 & 1 & 0.55 \\
\hline 19 Enterobacter sakazakii & 9 & 5.81 & 11 & 6.01 \\
\hline 20 Flavi. oryzihabitans & 1 & 0.64 & 3 & 1.64 \\
\hline 21 Hafnia alvei & 2 & 1.29 & 1 & 0.55 \\
\hline 22 Klebsiella pneum rhinosclero & 0 & 0 & 1 & 0.55 \\
\hline 23 Klebsiella ornitholytica & 3 & 1.94 & 1 & 0.55 \\
\hline 24 Klebsiella oxytoca & 1 & 0.64 & 0 & 0 \\
\hline 25 Klebsiella pпеит. рпеитопiae & 2 & 1.29 & 0 & 0 \\
\hline 26 Klebsiella terrigena & 3 & 1.94 & 0 & 0 \\
\hline 27 Morganella morganii & 1 & 0.64 & 0 & 0 \\
\hline 28 Myroides & 1 & 0.64 & 1 & 0.55 \\
\hline 29 Ochrobacter authrop. & 1 & 0.64 & 0 & 0 \\
\hline 30 Pantoea spp. & 2 & 1.29 & 2 & 1.09 \\
\hline 31 Pasteurella pneumoniae & 5 & 3.22 & 2 & 1.09 \\
\hline 32 Photobacterium damsela & 1 & 0.64 & 0 & 0 \\
\hline 33 Pnеuтососсиs & 1 & 0.64 & 1 & 0.55 \\
\hline 34 Proteus mirabilis & 5 & 3.22 & 4 & 2.18 \\
\hline 35 Proteus penneri & 0 & 0 & 1 & 0.55 \\
\hline 36 Proteus vulgaris & 5 & 3.22 & 3 & 1.64 \\
\hline 37 Providencia rettigeri & 1 & 0.64 & 0 & 0 \\
\hline 38 Pseudomonas aeruginosa & 12 & 7.74 & 12 & 6.56 \\
\hline 39 Pseudomonas fluorescens & 4 & 2.58 & 4 & 2.18 \\
\hline 40 Rhanella aquatilis & 2 & 1.29 & 0 & 0 \\
\hline 41 Salmonella arizonae & 4 & 2.58 & 11 & 6.01 \\
\hline 42 Salmonella spp. & 3 & 1.94 & 6 & 3.28 \\
\hline 43 Serratia marcescens & 6 & 3.87 & 11 & 6.01 \\
\hline 44 Serratia odorifera & 6 & 3.87 & 15 & 8.2 \\
\hline 45 Serratia ficarria & 4 & 2.58 & 2 & 1.9 \\
\hline 46 Serratia fonticola & 0 & 0 & 1 & 0.55 \\
\hline 47 Serratia liquefaciens & 11 & 7.09 & 9 & 4.92 \\
\hline 48 Serratia phymuthica & 1 & 0.64 & 0 & 0 \\
\hline 49 Serratia rubidaea & 0 & 0 & 1 & 0.55 \\
\hline 50 Shewanella putrefaciens & 1 & 0.64 & 1 & 0.55 \\
\hline 51 Stenotrophomonas maltophilia & 7 & 4.52 & 13 & 7.1 \\
\hline 52 Vibrio alginolyticus & 0 & 0 & 1 & 0.55 \\
\hline 53 Vibrio cholerae & 1 & 0.64 & 1 & 0.55 \\
\hline 54 Yersinia pseudotuberculosis & 0 & 0 & 1 & 0.55 \\
\hline Total number of isolates & 155 & & 183 & \\
\hline Total number of species & 41 & & 42 & \\
\hline Shannon-Weaver Index $(\mathrm{H})$ & 2.24 & & 2.84 & \\
\hline Evenness (e) & 1.39 & & 1.75 & \\
\hline
\end{tabular}


TABLE 2

Summarised seasonal bacterial community pattern expressed as percentage of occurrence of domestic water source samples from the Nkonkobe rural area in the Eastern Cape Province of South Africa, July 2001 to July 2002

\begin{tabular}{|c|c|c|c|c|c|c|c|c|c|}
\hline \multicolumn{2}{|c|}{ Bacterial species } & \multicolumn{2}{|c|}{ Summer } & \multicolumn{2}{|c|}{ Autumn } & \multicolumn{2}{|c|}{ Winter } & \multicolumn{2}{|c|}{ Spring } \\
\hline & & $\begin{array}{l}\text { No. of } \\
\text { isolates }\end{array}$ & $\%$ & $\begin{array}{l}\text { No. of } \\
\text { isolates }\end{array}$ & $\%$ & $\begin{array}{l}\text { No. of } \\
\text { isolates }\end{array}$ & $\%$ & $\begin{array}{c}\text { No. of } \\
\text { isolates }\end{array}$ & $\%$ \\
\hline 1 & Acinetobacter baumanni & 1 & 0.55 & 0 & 0 & 1 & 0.55 & 1 & 0.55 \\
\hline 2 & Aeromonas salm. salmonicida & 2 & 1.09 & 0 & 0 & 1 & 0.55 & 1 & 0.55 \\
\hline 3 & Aeromonas hydrophila gr. & 3 & 1.64 & 2 & 1.09 & 3 & 1.64 & 3 & 1.64 \\
\hline 4 & Burkholderia cepacia & 0 & 0 & 0 & 0 & 0 & 0 & 0 & 0 \\
\hline 5 & Cedecea davisae & 0 & 0 & 0 & 0 & 1 & 0.55 & 0 & 0 \\
\hline 6 & Chromo. violaceum & 0 & 0 & 0 & 0 & 2 & 1.09 & 1 & 0.55 \\
\hline 7 & Chryseomonas luteola & 2 & 1.09 & 4 & 2.18 & 6 & 3.28 & 0 & 0 \\
\hline 8 & Citrobacter koseri & 0 & 0 & 1 & 0.55 & 0 & 0 & 0 & 0 \\
\hline 9 & Citrobacter braakii & 1 & 0 & 0 & 0 & 0 & 0 & 0 & 0 \\
\hline 10 & Citrobacter freundii & 3 & 1.64 & 1 & 0.55 & 2 & 1.09 & 0 & 0 \\
\hline 11 & Citrobacter youngae & 1 & 0.55 & 0 & 0 & 0 & 0 & 0 & 0 \\
\hline 12 & Escherichia coli & 0 & 0 & 0 & 0 & 3 & 1.64 & 1 & 0.55 \\
\hline 13 & Enterobacter asburiae & 0 & 0 & 0 & 0 & 0 & 0 & 0 & 0 \\
\hline 14 & Enterobacter aerogenes & 0 & 0 & 0 & 0 & 1 & 0.55 & 0 & 0 \\
\hline 15 & Enterobacter amnigenus & 0 & 0 & 0 & 0 & 0 & 0 & 0 & 0 \\
\hline 16 & Enterobacter cloacae & 3 & 1.64 & 3 & 1.64 & 7 & 3.82 & 0 & 0 \\
\hline 17 & Enterobacter fergusoni & 0 & 0 & 0 & 0 & 1 & 0.55 & 0 & 0 \\
\hline 18 & Enterobacter gergoviae & 0 & 0 & 1 & 0.55 & 0 & 0 & 0 & 0 \\
\hline 19 & Enterobacter sakazakii & 4 & 2.18 & 0 & 0 & 7 & 3.82 & 0 & 0 \\
\hline 20 & Flavi. oryzihabitans & 0 & 0 & 1 & 0.55 & 2 & 1.09 & 0 & 0 \\
\hline 21 & Hafnia alvei & 1 & 0.55 & 0 & 0 & 0 & 0 & 0 & 0 \\
\hline 22 & Klebsiella pneum rhinosclero & 0 & 0 & 1 & 0.55 & 0 & 0 & 0 & 0 \\
\hline 23 & Klebsiella ornitholytica & 1 & 0.55 & 0 & 0 & 0 & 0 & 0 & 0 \\
\hline 24 & Klebsiella oxytoca & 0 & 0 & 0 & 0 & 0 & 0 & 0 & 0 \\
\hline 25 & Klebsiella pneum. pneumoniae & 0 & 0 & 0 & 0 & 0 & 0 & 0 & 0 \\
\hline 26 & Klebsiella terrigena & 0 & 0 & 0 & 0 & 0 & 0 & 0 & 0 \\
\hline 27 & Morganella morganii & 0 & 0 & 0 & 0 & 0 & 0 & 0 & 0 \\
\hline 28 & Myroides & 0 & 0 & 0 & 0 & 1 & 0.55 & 0 & 0 \\
\hline 29 & Ochrobacter authrop. & 0 & 0 & 0 & 0 & 0 & 0 & 0 & 0 \\
\hline 30 & Pantoea spp. & 1 & 0.55 & 1 & 0.55 & 0 & 0 & 0 & 0 \\
\hline 31 & Pasteurella pneumoniae & 0 & 0 & 1 & 0.55 & 1 & 0.55 & 0 & 0 \\
\hline 32 & Photobacterium damsela & 0 & 0 & 0 & 0 & 0 & 0 & 0 & 0 \\
\hline 33 & Pneumococcus & 0 & 0 & 0 & 0 & 1 & 0.55 & 0 & 0 \\
\hline 34 & Proteus mirabilis & 1 & 0.55 & 1 & 0.55 & 1 & 0.55 & 1 & 0.55 \\
\hline 35 & Proteus penneri & 0 & 0 & 1 & 0.55 & 0 & 0 & 0 & 0 \\
\hline 36 & Proteus vulgaris & 2 & 1.09 & 0 & 0 & 1 & 0.55 & 0 & 0 \\
\hline 37 & Providencia rettigeri & 0 & 0 & 0 & 0 & 0 & 0 & 0 & 0 \\
\hline 38 & Pseudomonas aeruginosa & 1 & 0.55 & 4 & 2.18 & 5 & 2.73 & 2 & 1.09 \\
\hline 39 & Pseudomonas fluorescens & 0 & 0 & 0 & 0 & 4 & 2.18 & 0 & 0 \\
\hline 40 & Rhanella aquatilis & 0 & 0 & 0 & 0 & 0 & 0 & 0 & 0 \\
\hline 41 & Salmonella arizonae & 5 & 2.73 & 0 & 0 & 4 & 2.18 & 2 & 1.09 \\
\hline 42 & Salmonella spp & 3 & 1.64 & 0 & 0 & 3 & 1.64 & 0 & 0 \\
\hline 43 & Serratia marcescens & 4 & 2.18 & 2 & 1.09 & 3 & 1.64 & 2 & 1.09 \\
\hline 44 & Serratia odorifera & 2 & 1.09 & 1 & 0.55 & 12 & 6.56 & 0 & 0 \\
\hline 45 & Serratia ficarria & 1 & 0.55 & 1 & 0.55 & 0 & 0 & 0 & 0 \\
\hline 46 & Serratia fonticola & 0 & 0 & 0 & 0 & 1 & 0.55 & 0 & 0 \\
\hline 47 & Serratia liquefaciens & 1 & 0.55 & 0 & 0 & 7 & 3.82 & 1 & 0.55 \\
\hline 48 & Serratia phymuthica & 0 & 0 & 0 & 0 & 0 & 0 & 0 & 0 \\
\hline 49 & Serratia rubidaea & 0 & 0 & 0 & 0 & 1 & 0.55 & 0 & 0 \\
\hline 50 & Shewanella putrefaciens & 1 & 0.55 & 0 & 0 & 0 & 0 & 0 & 0 \\
\hline 51 & Stenotrophomonas maltophilia & 2 & 1.09 & 2 & 1.09 & 4 & 2.18 & 5 & 2.73 \\
\hline 52 & Vibrio alginolyticus & 0 & 0 & 0 & 0 & 1 & 0.55 & 0 & 0 \\
\hline 53 & Vibrio cholerae & 0 & 0 & 0 & 0 & 1 & 0.55 & 0 & 0 \\
\hline 54 & Yersinia pseudotuberculosis & 1 & 0.55 & 0 & 0 & 0 & 0 & 0 & 0 \\
\hline & Total & 47 & 25.7 & 28 & 15.32 & 88 & 48.1 & 20 & 10.94 \\
\hline
\end{tabular}


TABLE 3

Summarised seasonal bacterial community pattern expressed as percentage of occurrence of domestic water source samples from the Gogogo rural area in the Eastern Cape Province of South Africa, July 2001 to July 2002

\begin{tabular}{|c|c|c|c|c|c|c|c|c|}
\hline Bacterial species & \multicolumn{2}{|c|}{ Summer } & \multicolumn{2}{|c|}{ Autumn } & \multicolumn{2}{|c|}{ Winter } & \multicolumn{2}{|c|}{ Spring } \\
\hline & $\begin{array}{l}\text { No. of } \\
\text { isolates }\end{array}$ & $\%$ & $\begin{array}{c}\text { No. of } \\
\text { isolates }\end{array}$ & $\%$ & $\begin{array}{l}\text { No. of } \\
\text { isolates }\end{array}$ & $\%$ & $\begin{array}{c}\text { No. of } \\
\text { isolates }\end{array}$ & $\%$ \\
\hline Acinetobacter baumanni & 0 & 0 & 0 & 0 & 0 & 0 & 0 & 0 \\
\hline 2 Aeromonas salm. salmonicida & 1 & 0.64 & 0 & 0 & 0 & 0 & 0 & 0 \\
\hline 3 Aeromonas hydrophila gr. & 1 & 0.64 & 2 & 1.29 & 0 & 0 & 6 & 3.87 \\
\hline $4 \quad$ Burkholderia cepacia & 1 & 0.64 & 0 & 0 & 0 & 0 & 0 & 0 \\
\hline Cedecea davisae & 0 & 0 & 0 & 0 & 0 & 0 & 0 & 0 \\
\hline Chromo. violaceum & 0 & 0 & 0 & 0 & 0 & 0 & 0 & 0 \\
\hline $7 \quad$ Chryseomonas luteola & 0 & 0 & 3 & 1.94 & 5 & 3.22 & 1 & 0.64 \\
\hline Citrobacter koseri & 0 & 0 & 0 & 0 & 0 & 0 & 0 & 0 \\
\hline $9 \quad$ Citrobacter braakii & 1 & 0.64 & 0 & 0 & 2 & 1.29 & 0 & 0 \\
\hline 10 Citrobacter freundii & 0 & 0 & 0 & 0 & 2 & 1.29 & 0 & 0 \\
\hline 11 Citrobacter youngae & 0 & 0 & 0 & 0 & 0 & 0 & 0 & 0 \\
\hline 12 Escherichia coli & 0 & 0 & 0 & 0 & 2 & 1.29 & 1 & 0.64 \\
\hline 13 Enterobacter asburiae & 0 & 0 & 0 & 0 & 1 & 0.64 & 0 & 0 \\
\hline 14 Enterobacter aerogenes & 0 & 0 & 0 & 0 & 0 & 0 & 0 & 0 \\
\hline 15 Enterobacter amnigenus & 1 & 0.64 & 0 & 0 & 1 & 0.64 & 0 & 0 \\
\hline 16 Enterobacter cloacae & 1 & 0.64 & 5 & 3.22 & 11 & 7.09 & 0 & 0 \\
\hline 17 Enterobacter fergusoni & 0 & 0 & 0 & 0 & 0 & 0 & 0 & 0 \\
\hline 18 Enterobacter gergoviae & 0 & 0 & 0 & 0 & 1 & 0.64 & 0 & 0 \\
\hline 19 Enterobacter sakazakii & 4 & 2.58 & 3 & 1.94 & 2 & 1.29 & 0 & 0 \\
\hline 20 Flavi. oryzihabitans & 0 & 0 & 0 & 0 & 1 & 0.64 & 0 & 0 \\
\hline 21 Hafnia alvei & 1 & 0.64 & 0 & 0 & 1 & 0.64 & 0 & 0 \\
\hline 22 Klebsiella pneum rhinosclero & 0 & 0 & 0 & 0 & 0 & 0 & 0 & 0 \\
\hline 23 Klebsiella ornitholytica & 0 & 0 & 0 & 0 & 3 & 1.94 & 0 & 0 \\
\hline 24 Klebsiella oxytoca & 0 & 0 & 0 & 0 & 1 & 0.64 & 0 & 0 \\
\hline 25 Klebsiella pneum. pneumoniae & 0 & 0 & 1 & 0.64 & 1 & 0.64 & 0 & 0 \\
\hline 26 Klebsiella terrigena & 0 & 0 & 0 & 0 & 3 & 1.94 & 0 & 0 \\
\hline 27 Morganella morganii & 1 & 0.64 & 0 & 0 & 0 & 0 & 0 & 0 \\
\hline 28 Myroides & 0 & 0 & 1 & 0.64 & 0 & 0 & 0 & 0 \\
\hline 29 Ochrobacter authrop. & 0 & 0 & 0 & 0 & 1 & 0.64 & 0 & 0 \\
\hline $30 \quad$ Pantoea spp. & 0 & 0 & 1 & 0.64 & 1 & 0.64 & 0 & 0 \\
\hline 31 Pasteurella pneumoniae & 1 & 0.64 & 2 & 1.29 & 2 & 1.29 & 0 & 0 \\
\hline 32 Photobacterium damsela & 1 & 0.64 & 0 & 0 & 0 & 0 & 0 & 0 \\
\hline 33 Pneumococcus & 0 & 0 & 0 & 0 & 1 & 0.64 & 0 & 0 \\
\hline 34 Proteus mirabilis & 4 & 2.58 & 1 & 0.64 & 0 & 0 & 0 & 0 \\
\hline 35 Proteus penneri & 0 & 0 & 0 & 0 & 0 & 0 & 0 & 0 \\
\hline 36 Proteus vulgaris & 4 & 2.58 & 0 & 0 & 1 & 0.64 & 0 & 0 \\
\hline 37 Providencia rettigeri & 1 & 0.64 & 0 & 0 & 0 & 0 & 0 & 0 \\
\hline 38 Pseudomonas aeruginosa & 3 & 1.94 & 2 & 1.29 & 2 & 1.29 & 5 & 3.22 \\
\hline 39 Pseudomonas fluorescens & 1 & 0.64 & 0 & 0 & 0 & 0 & 3 & 1.94 \\
\hline 40 Rhanella aquatilis & 2 & 1.29 & 0 & 0 & 0 & 0 & 0 & 0 \\
\hline 41 Salmonella arizonae & 2 & 1.29 & 0 & 0 & 2 & 1.29 & 0 & 0 \\
\hline 42 Salmonella spp & 1 & 0.64 & 0 & 0 & 2 & 1.29 & 0 & 0 \\
\hline 43 Serratia marcescens & 1 & 0.64 & 1 & 0.64 & 4 & 2.58 & 0 & 0 \\
\hline 44 Serratia odorifera & 0 & 0 & 2 & 1.29 & 4 & 2.58 & 0 & 0 \\
\hline 45 Serratia ficarria & 0 & 0 & 0 & 0 & 4 & 2.58 & 0 & 0 \\
\hline 46 Serratia fonticola & 0 & 0 & 0 & 0 & 0 & 0 & 0 & 0 \\
\hline 47 Serratia liquefaciens & 1 & 0.64 & 1 & 0.64 & 7 & 4.52 & 2 & 1.29 \\
\hline 48 Serratia phymuthica & 1 & 0.64 & 0 & 0 & 0 & 0 & 0 & 0 \\
\hline 49 Serratia rubidaea & 0 & 0 & 0 & 0 & 0 & 0 & 0 & 0 \\
\hline 50 Shewanella putrefaciens & 0 & 0 & 0 & 0 & 1 & 0.64 & 0 & 0 \\
\hline 51 Stenotrophomonas maltophilia & 0 & 0 & 1 & 0.64 & 2 & 1.29 & 4 & 2.58 \\
\hline 52 Vibrio alginolyticus & 0 & 0 & 0 & 0 & 0 & 0 & 0 & 0 \\
\hline 53 Vibrio cholerae & 0 & 0 & 1 & 0.64 & 0 & 0 & 0 & 0 \\
\hline 54 Yersinia pseudotuberculosis & 0 & 0 & 0 & 0 & 0 & 0 & 0 & 0 \\
\hline Total & 35 & 22.5 & 27 & 17.38 & 71 & 45.74 & 22 & 14.18 \\
\hline
\end{tabular}


dominant organism in Gogogo water sources. On the other hand in winter the water sources dry up and as a result of this, animals tend to flock to any available water source, including the ones used by the community for drinking, therefore increasing the level of contamination.

Seasonal distributions of species in water sources from the two rural areas were also determined. As seen in Tables 2 and 3 the highest percentage of bacteria for both regions was observed in winter, Gogogo $-45.74 \%$ and Nkonkobe $-48.1 \%$. The lowest percentage of micro-organisms was noticed in spring $14.18 \%$ for Gogogo waters and $10.94 \%$ for Nkonkobe. The quantity of bacteria was relatively high in summer as well $-22.5 \%$ for Gogogo water sources and $25.7 \%$ for Nkonkobe (Tables 2 and 3). The percentage of micro-organisms in autumn was $17.38 \%$ for Gogogo domestic water sources and $15.32 \%$ for Nkonkobe ones. Overall, the percentages of micro-organisms with regard to the different seasons were in the following order: winter> summer> autumn> spring.

The high values of bacteria in the summer season $-22.5 \%$ for Gogogo domestic water sources and $25.7 \%$ for Nkonkobe water sources can be explained by the fact that high temperatures favoured the growth of E. coli, Salmonella spp., Proteus spp. and similar species. The low number of micro-organisms in spring and autumn in both of the water sources studied might be explained by the fact that these are transient seasons from cold to hot weather and from hot to cold weather, often accompanied by heavy rainfalls. These are periods during which micro-organisms adapt to the environmental changes and since this adaptation goes along with changes in their regulation of protein, RNA and DNA synthesis, it might be accompanied by the die-down of a substantial number of bacteria.

\section{Conclusions}

The domestic water sources in both the Gogogo and the Nkonkobe rural areas of the Eastern Cape showed high levels of contamination, predominantly by species of the Enterobacteriacae family. The level of seasonal contamination followed the order winter $>$ summer $>$ autumn $>$ spring. Water from all the domestic water sources under consideration needs extensive and efficient purification, so that its quality meets the South African Standards for drinking water. This will prevent the periodical outbreaks of a number of serious water-borne diseases, such as typhoid fever, salmonellosis, shigellosis, enteritis, enterocolitis, to name a few, which can be fatal.

\section{Acknowledgement}

This work was supported by a South Africa-Netherlands Research Programme on Alternatives in Development (SANPAD) research grant. We are also thankful to the NRF and the Canon Collins Educational Trust for Southern Africa (CCETSA) for a M.Sc. degree bursary to the first author and additional API 20E kits, respectively.

\section{References}

BRIGGS D, CORVALANC and NURMINEN M (1996) Linkage Methods for Environmental Health Analysis. World Health Organization WHO, EHG 95.26, Geneva.

CLAYTON J (1999) Changing trends in the laboratory diagnosis of gastroenteric infections. Nursing Standard 14 (11) 42-46.

DEPARTMENT OF WATER AFFAIRS and FORESTRY (DWAF) (1986) Management of the Water Resources of Republic of South Africa. CTP Book Printers, Cape Town. 1-176.

DEPARTMENT OF WATER AFFAIRS and FORESTRY (DWAF) (1998) Quality of Domestic Water Supplies - Vol. 1 Assessment Guide. Department of Water Affairs and Forestry, Pretoria.

GEISSLER K, MANAFI M, AMOROS I and ALONSO JL (2000) Quantitative determination of total coliforms and Escherichia coli in marine waters with chromogenic and fluorogenic media. J. Appl. Microbiol. 88 (5) 280-285.

GRABOW NA, KFIR R and GRABOW WOK (1991) A most probable number method for the enumeration of Legionella bacteria in water. Water Sci. 24 (7) 143-147.

JUANG DF and MORGAN JM (2001) The application of the API 20E and API Rapid NFT systems for the identification of bacteria from activated sludge. Environ. Biotechnol. 4 (1) 1-6.

MIMMS CA (1990) Pathogenesis of Infectious Disease. Academic Press. London. 125-137.

MUYIMANYO and NGCAKANIF (1998) Indicator bacteria and regrowth potential of the drinking water in Alice, Eastern Cape. Water SA 24 (1) 29-34.

PRESCOTT LM, HARLEY JP and KLEIN DA (1999) Microbiology. WCB McGraw-Hill Publishers, Dubuque. 477-487.

VON S SCHIRNDING YE (1992) Morbidity amongst bathers exposed to polluted Sea water - A prospective study. S. Afr. J. Medicine 81 (11) 36-47.

ZAMXAKA M, PIRONCHEVA G and MUYIMA NYO (2004) The status quo with regard to the quality of domestic water sources in selected rural communities of the Eastern Cape Province, South Africa. Water SA 30 (3) 333-340. 